\title{
Human Energy in Organization: Leadership as a Means for Creating Team Performance in Adult Education
}

\author{
DAnna Kvelde Mg. arts \\ RISEBA University of Applied Sciences, Latvia \\ anna.kvelde@gmail.com
}

\begin{abstract}
The productive team energy is important at work and in organizational psychology as it aims to promote human energy. Human energy is more than just a "New Age" concept, it has a substantial and predictable effects on performance and innovation in organizations. The aim of the study is to examine relations between leadership style and team performance and mediating role is played by the productive organizational energy. The study is based on literature and quantitative and qualitative research methods. The theoretical framework is assessed in an empirical study in Latvian organizations in 2019. The study was accomplished in co-operation with American company "The Energy Project" and University of Arizona. The article reveals human energy model as a scientifically based approach and transformational leadership as a development tool, which already has spread in all sectors of western society, including educational organizations. The article presents significance for practical purposes, as it can help organizations in analysing their current situation on the team performance. The materials and recommendations can be used to assist and help organizations in identifying practices, processes and initiatives, which can have a positive impact on team performance and organizational energy. The general conclusion is that the transformation leadership lays a positive dynamic in the development of the productive team performance. The educational organizations can progress and create the productive performance in a particularly manner by focusing on their human resources; considering their growth, development and well-being in adult education.
\end{abstract}

Keywords: adult education, transformational leadership style, team performance, productive organizational energy.

\section{Introduction}

At the present stage of development of education teachers are technology-oriented and responsible not only for teaching, but also for the organization of students' learning, as a result, increased stressful situations, work long hours and are tethered to work through technology. The symptoms of teacher's stress contributing to burnout have been extensively studied (Helou, Nabhani, 2016; Jacobson, 2016). A. Leme and I. Maia (2015) inferred that teachers feel depleted with little personal human energy for family or community activities; teachers' fatigue causes motivation and well-being reduction and as a result increase poor performance.

These issues together defined the problem of the study, which is to improve the teacher's well-being and work- related performance. Referring to the analysis of the initial facts and the problem, authors were highlighted the innovative topics of research: firstly, the ability to maintain personal human energy and to use it correctly for leadership at the workplace; secondly, the capacity to build new communication methods or relational energy, that should become an essential tool for managing the pedagogical process and improving productive team performance in adult education.

Interest in personal human energy flourished in the 1970s, when H.J. Freudenberger (1975) became interested in burnout, mental fatigue, and mental distancing from work. This leads scholars to realize the influential role of human energy on the individual and organizational levels (Luthans, Avolio, 2009). Important to mention that in Eastern philosophy " $Q i$ '" (life power or energy flow) is a concept that is often mentioned in relation to physical and mental health, but in Western philosophy and theory it remains more unexplored. This has changed in the beginning of the 21th century, more attention is being paid to positive psychology, positive energy and the study of positive social interactions for optimal human functioning (Heaphy, Dutton, 2008). The study begins by looking across the interdisciplinary literature on human energy to each of the theories that examine productive team and organizational performance. 
B.L. Rich, J.A. Lepine and E.R. Crawford in their study emphasized that human energy is one operative and defining characteristic of work engagement. The researchers presented a three-part measure of work engagement, where were combined physical, cognitive, and emotional human energy one experiences at work (Rich, Lepine, Crawford, 2010). The study of R.M. Ryan and C.M. Frederick (1997) have indeed shown a positive relationship between human energy and vitality and well-being. S.E. Hobfoll and A. Shirom (2000) also expressed that human energy helps people regulate their behaviours and emotions in compliance with organizational or group norms and expectations. A. Carmeli and G.M. Spreitzer confirmed that human energy as a resource demonstrated positive outcomes including performance and creativity. The researchers emphasize that one of the key roles in the successful development of productive team performance is occupied by leaders' behaviour (Carmeli, Spreitzer, 2009).

Leadership is a concept that is strongly related to the topic of human resource development, it is about empowering people to achieve their full potential and work towards the concept of self-actualization intellectually (Hargreaves, Fink, 2006). Based on theoretical analyses different leadership theories were explored and found that human energy resources had influenced the birth of transformational leadership theory. B.M. Bass (1998) described transformational leadership in terms of the impact that it has on followers; followers feel trust, admiration, and loyalty towards the leader. Transformational leaders boost their followers' performance through human energy as a resource (Bass, 1998). The results of the study about transformational leadership in the school environment has shown that it fosters teacher development such as providing intellectual stimulation, offering individualizes support, modelling best practices and value, demonstrating high performance expectations and creating a productive teaching culture (Leithwood, Tomlinson, Genge, 1996).

Adult education teachers are a diverse group who work with a variety of diverse student populations with many different learning needs and goals (Teacher Effectiveness in..., 2020). The analysis of the literature and results of empirical practice has allowed concluding that transformational leadership can become a means for creating team performance in adult education.

The aim of the study is to examine the relations between leadership style and team performance and the mediating role is played by the productive organizational energy.

\section{Theoretical background}

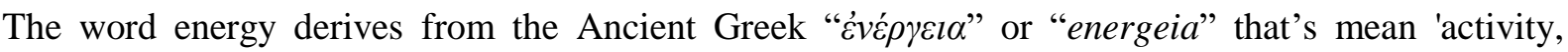
operation', which appears for the first time in the work of Aristotle in the 4th century BC and it described qualitative philosophical concepts, which fuels one's potentiality (Witt, 2003). In the study human energy definition is used from Lexico Oxford Dictionary with meaning as "the strength and vitality required for sustained physical or cognitive activity" (Lexico..., 2021).

Three kinds of human energy dimensions are discerned:

- mental and spiritual energy (being able to intensely focus) (Baker, 2019);

- physical energy (strength, endurance, flexibility) (Baker, 2019);

- emotional energy/ relation energy (being in touch with feelings and core values) (Baker, 2019).

W.E. Baker (2019) suggested an altered category labelled "emotional" energy to "relational" energy, and in his study identified the powerful role that relational human energy plays in corporate behaviour. E. Kř́ž described the importance of the personality of the teacher and the influence on the relations between teacher and students, he also expressed that students should respect their teacher like a real personality with positive attributes. These features of personality: ability, temperament, character, motivation, needs, interests, aspirations, attitude, knowledge and skills should be characteristic for a teacher of practical teaching (Kř́ž, 2013). The research about relational human energy reported that it has enclosed high-quality relationships at work, generate and sustain energetic resources, motivate people to do work well and positively associated with team performance (Quinn, Dutton, 2005).

The analysis of the literature has allowed concluding that human energy resources have influenced the birth of transformational leadership theory. B.M. Bass (1998) defined transformational leaders as people who mentor and encourage both colleagues and followers, they are ones who maintain their own human energy. In the study components are specified, which create the framework for transformational leadership considering them as behaviours. These four components are known as 'four I's': idealized 
influence, inspirational motivation, intellectual stimulation, individualized consideration (Luthans, Avolio, 2009). Transformational leaders articulate a vision for the future, act as charismatic role models, set high performance expectations, provide individualized support, and stimulate followers. Transformational leadership has been found to be related: to follower performance, to job satisfaction, to organisational identification and to organisational commitment (Schwartz, Gomez, McCarthy, 2010).

Transformational leadership is a model that principals and teachers can use to lead by example in adult education, it places a high value on creating community bonds, which encourage both students and teachers to greater levels of achievement and behavioural patterns perceived and adopted by young people (Teacher Effectiveness..., 2020). According to S.S. Khumalo (2012) transformational leadership style views relationship development as a crucial component of the work of educational institutions. Transformational leadership in education spurs students and teachers to expand and grow in a nurturing community. One of the strengths of the transformational leadership model is that it builds on the resources of every member of the school, particularly staff, teachers and students (Khumalo, 2012). The benefits of transformational leadership: firstly, fosters a community that is committed to the goals of the school and the success of all students, secondly, effect of this style of leadership is educational change. This provides an environment that fosters the creation of new and innovative instructional techniques.

The model of "Human Energy in Organizations" (HEO) is a scientifically based approach to energizing people physically, emotionally, mentally and spiritually so they can perform sustainably at their best is explained. The model consists of four components: human energy, transformational leadership, productive team energy and productive organizational energy. The main basic components of $\mathrm{HEO}$ model are human energy and transformational leadership, the consolidation of them leads to productive team and organizational energy. T. Schwartz, J. Gomez and C. McCarthy (2010) research points out to a great importance of productive team energy, the researchers state that it integrates personal and relation human energy into four dimensions - mindset, culture, structure and behaviour, and is an effective helping system for successful organizational transformation. M.S. Cole, H. Bruch and B. Vogel (2008) research about productive organizational energy (POE) explained that it refers to the shared experience and demonstration of positive affect and behaviours among followers in their joint pursuit of organizationally salient objectives. POE is linked to such critical organizational aspects as: well-being, internal effectiveness and organizational performance (Kenny, 2019). All components of the model of HEO are interrelated (Figure 1).

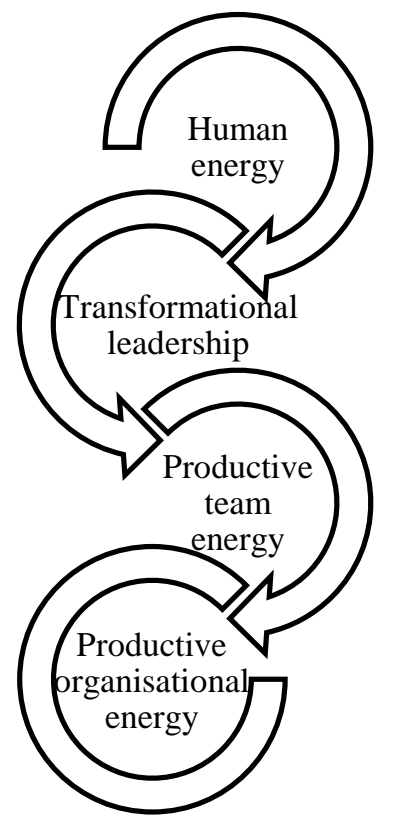

Figure 1. Model of Human Energy in Organization (developed by the author).

Implementation of "Model of Energy in Organization" in an educational institution will lead to increased team performance, it is indicated by group-produced output, the consequences a group has for its members and the enhancement of a team's capability to perform effectively in the future (Sun, Xu, Shang, 2014). 


\section{Methodology}

The aim of the empirical study is to examine the effect of transformational leadership on productive organization energy and the mediating role is played by the productive organizational energy. A mediating variable or "mediator" is an integral part of a cause-and-effect relationship. Mediator makes it easier to understand how the independent variable is affecting the dependent variable and what is governing that relationship (Swaen, 2015). A quantitative and qualitative methodology was reasoned to be best-suited, because it is systematically measured variables with the aim of explaining and predicting the phenomena and it enabled each question to be statistically tested and the results generalised to the population of studies. In the study conceptual framework is illustrated (Figure 2).

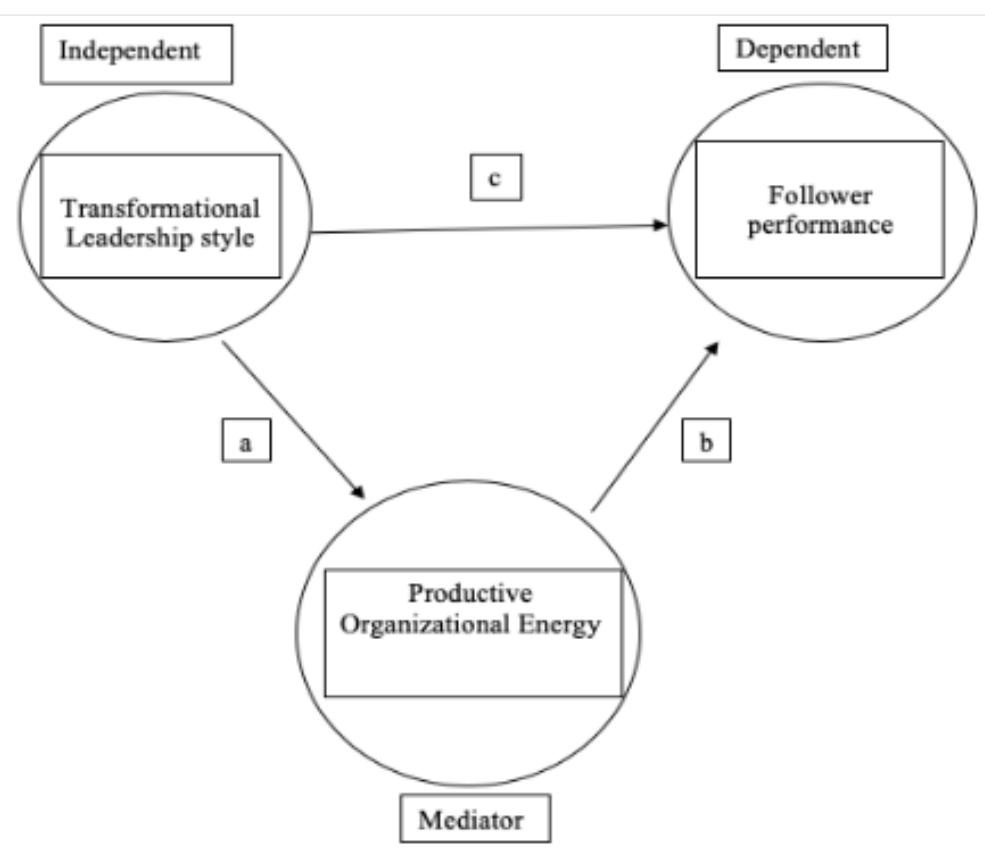

Figure 2. Research Conceptual Framework (developed by the author).

Research questions: (1) Which aspects of transformational leadership relate to higher productive organisational energy and team performance? (2) How organizational energy relates to team performance? (3) Which leadership behaviours lead to sustainable productive team energy?

The population of research consisted of 10 public and private organizations, which included 4 educational organizations. Research subject: leaders with 10 years' experience and their teams. The research focused on the perception of followers and leaders. The stratified sample types were used in the research. For examining respondents, a convenience sample was taken from a diverse group of learners/employees of various organizations in Latvia. Respondents of this sample were females (56\%) and males (44\%). Most of the respondents are organizational teachers/managers in different departments $(74 \%)$, employed for 0-10 years in their company (85\%), work experience of $0-10$ years (54\%) and work experience of 10-20 years (46\%).

\section{Research Instruments and Measures:}

1. Leaders survey content has 4 parts: Personal Information, The Multifactor Leadership Questionnaire (MLQ) (Rowold, 2005), Team performance (Sun, Xu, Shang, 2014), Productive Organizational Energy (Cole, Bruch, Vogel, 2008).

2. Followers' survey content has 4 parts: Personal Information, Productive Organizational Energy, Team Performance (Sun, Xu, Shang, 2014), The Subjective Vitality (Ryan, Frederick, 1997).

Methods of data collection: (1) questionnaire, (2) observation, (3) interview.

Data Analysis Procedure: IBM SPSS 21.0, the Statistical Program for Social Sciences was used in this research to process, evaluate and present the data collected during the research process. Mediation model was used for evaluating the impact of one variable on another while the relationship is mediated by a third factor. The model consists of multiple steps that use multiple linear regression for establishing relationships. The second tool for analysis is the combined use of correlation and regression analysis. 
Correlation analysis helps in establishing the sign of relationships observed between different variables, regression analysis in SPSS helped evaluating the relationships between different variables.

\section{Results and Discussion}

Research Question 1: Which transformational leadership behaviours relate to higher productive organizational energy and team performance?

The research presents the correlation coefficients of all 21 leader`s behaviour in relation to POE and Team Performance as evaluated by followers, to answer the first research question (Table 1).

Table 1

The correlation coefficients of Leader`s behaviour with Productive Organizational Energy and Team Performance

\begin{tabular}{|l|l|c|c|}
\hline No. & \multicolumn{1}{|c|}{ Leader's behaviour (LEB) } & $\begin{array}{c}\text { POE } \\
\text { (followers) }\end{array}$ & $\begin{array}{c}\text { Team } \\
\text { Performance } \\
\text { (followers) }\end{array}$ \\
\hline 1 & I make others feel good to be around me & -.12 & -.06 \\
\hline 2 & I express with a few simple words what we could and should do & -.03 & $.0,8$ \\
\hline 3 & I enable others to think about old problems in new ways & .14 & -.27 \\
\hline 4 & I help others develop themselves &. $\mathbf{3 5}$ & .07 \\
\hline 5 & I tell others what to do if they want to be rewarded for their work. &. $\mathbf{2 6}$ & -.05 \\
\hline 6 & I am satisfied when others meet agreed-upon standards & .07 & .06 \\
\hline 7 & I am content to let others continue working in the same ways always. & -.09 & .07 \\
\hline 8 & Others have complete faith in me & .07 & .06 \\
\hline 9 & I provide appealing images about what we can do & .15 & -.13 \\
\hline 10 & I provide others with new ways of looking at puzzling things. & -.13 & -.09 \\
\hline 11 & I let others know how I think they are doing. & -.04 & -.11 \\
\hline 12 & I provide recognition/rewards when others reach their goals & .25 & -.04 \\
\hline 13 & As long as things are working, I do not try to change anything. & .05 & -.25 \\
\hline 14 & Whatever others want to do is OK with me & -1.2 & -.12 \\
\hline 15 & Others are proud to be associated with me. & $\mathbf{. 2 9}$ & -.13 \\
\hline 16 & I help others find meaning in their work. & .09 & .21 \\
\hline 17 & I get others to rethink ideas that they had never questioned before & .14 &. $\mathbf{3 6}$ \\
\hline 18 & I give personal attention to others who seem rejected & $\mathbf{. 2 2}$ & -.19 \\
\hline 19 & I call attention to what others can get for what they accomplish & -.04 & -.01 \\
\hline 20 & I tell others the standards they have to know to carry out their work. & $\mathbf{. 2 1}$ \\
\hline 21 & I ask no more of others than what is absolutely essential. & .15 \\
\hline
\end{tabular}

According to the data, the recommended leader's behaviour related to higher POE and Team Performance as perceived by followers are pointed with bold. There is a significant positive correlation between leadership behaviours and higher POE and team performance as perceived by followers: $L E B 4$ $r=0.35$; LEB $5 r=0.26$; LEB12 $r=0.25 ;$ LEB15 $r=0.25 ;$ LEB16 $r=0.21 ; L E B 17 r=0.36 ; L E B 19 r=0.22$; $L E B 20 r=0.21$; LEB $21 r=0.21$.

In contrast, the not recommended leaders` behaviour related to lower POE and team performance are those who have significant negative correlation and are pointed in italics in Table 1 . There is significant negative correlation between behaviours LEB3, $r=-0,27 ;$ LEB13, $r=-0,25, L E B 18, r=-0,24$.

\section{Research Question 2: How Productive Organizational Energy relates to Team Performance?}

There is a positive correlation between POE and team performance of followers $(r=0.710, p<0.001)$. It means that higher organizational energy is significantly and positively related to team performance and can be expected higher performance if higher energy is presented. Based on the correlation results some leadership behaviours are related to team performance, but most of them are related to productive organization energy (Figure 3). 

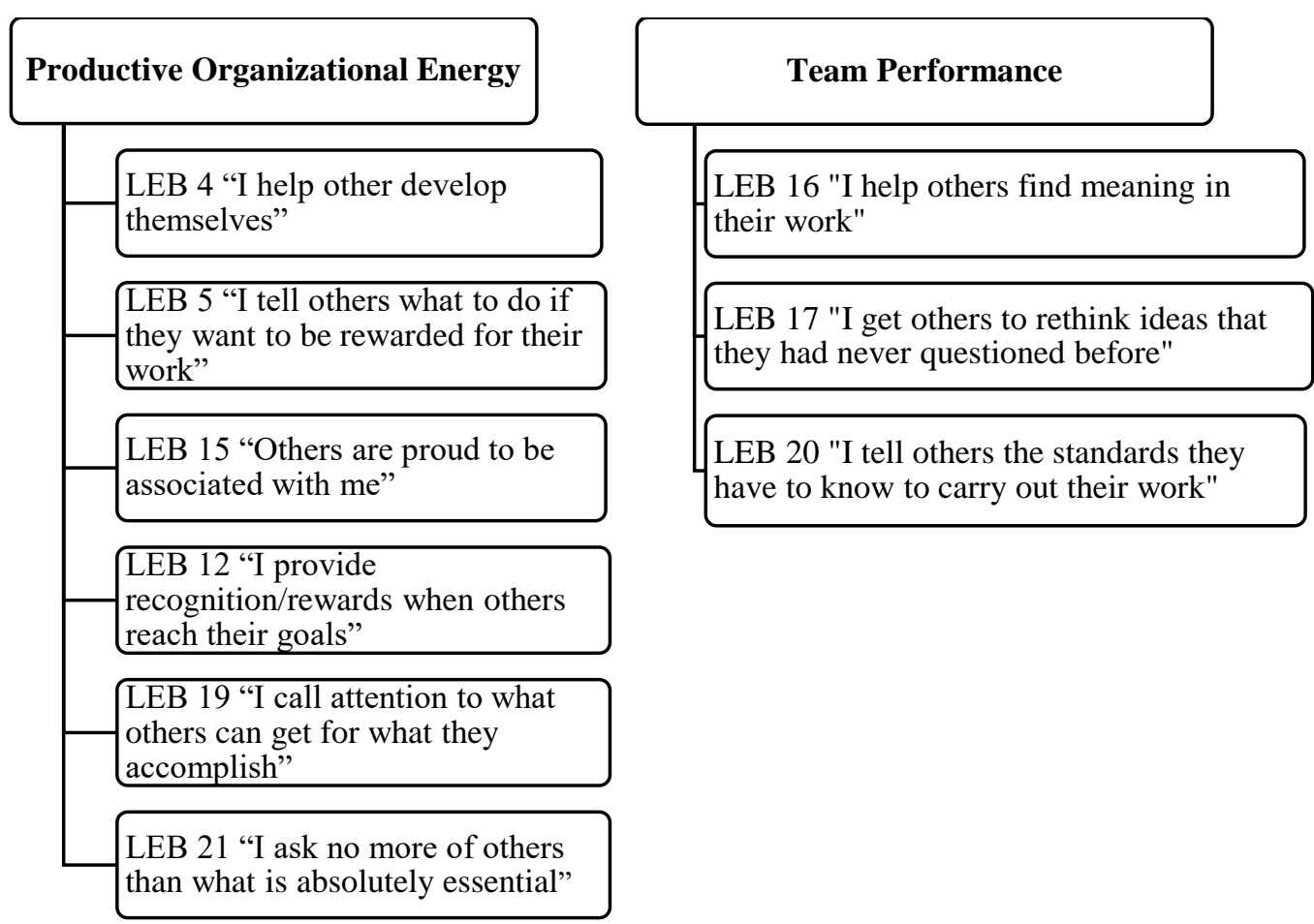

Figure 3. Summary of leadership behaviours that have positive impact on Productive Organization Energy and Team Performance.

Research question 3: Which leadership behaviours lead to sustainable productive team energy?

The research was aimed to analyse the positive impact of different leadership behaviours on productive organization energy and team performance. The MLQ consisted of 7 leadership factors, with 3 different leadership behaviours. Summary of MLQ Leadership factors is presented in Table 2.

Table 2

Summary of The Multifactor Leadership Questionnaire Leadership factors

\begin{tabular}{|c|c|c|c|c|}
\hline Nr. & $\begin{array}{l}\text { Leadership } \\
\text { factors }\end{array}$ & Leadership behaviours & $\begin{array}{c}\text { POE } \\
\text { followers }\end{array}$ & $\begin{array}{c}\text { Team } \\
\text { Performance } \\
\text { followers }\end{array}$ \\
\hline 1. & \multirow{3}{*}{$\begin{array}{l}\text { F:1 Idealised } \\
\text { influence }\end{array}$} & I make others feel good to be around me & -.12 & -.06 \\
\hline 8. & & Others have complete faith in me & .07 & .06 \\
\hline 15. & & Others are proud to be associated with me. & .29 & -.13 \\
\hline 2. & \multirow{3}{*}{$\begin{array}{l}\text { F2: } \\
\text { Inspirational } \\
\text { motivation }\end{array}$} & I express with a few simple words what we could and should do & -.03 & $.0,8$ \\
\hline 9. & & I provide appealing images about what we can do & .15 & -.13 \\
\hline 16. & & I help others find meaning in their work. & .09 & .21 \\
\hline 3. & \multirow{3}{*}{$\begin{array}{l}\text { F3: } \\
\text { Intellectual } \\
\text { stimulation }\end{array}$} & I enable others to think about old problems in new ways & .14 & -.27 \\
\hline 10. & & I provide others with new ways of looking at puzzling things. & -.13 & -.09 \\
\hline 17. & & $\begin{array}{l}\text { I get others to rethink ideas that they had never } \\
\text { questioned before }\end{array}$ & .14 & .36 \\
\hline 4. & \multirow{3}{*}{$\begin{array}{l}\text { F4: } \\
\text { Individual } \\
\text { consideration }\end{array}$} & I help others develop themselves & .35 & .07 \\
\hline 11. & & I let others know how I think they are doing. & -.04 & -.11 \\
\hline 18. & & I give personal attention to others who seem rejected & -.24 & -.19 \\
\hline 5. & \multirow{3}{*}{$\begin{array}{l}\text { F5: } \\
\text { Contingent } \\
\text { reward }\end{array}$} & $\begin{array}{l}\text { I tell others what to do if they want to be rewarded for } \\
\text { their work. }\end{array}$ & .26 & -.05 \\
\hline 12. & & $\begin{array}{l}\text { I provide recognition/rewards when others reach their } \\
\text { goals }\end{array}$ & .25 & -.04 \\
\hline 19. & & $\begin{array}{l}\text { I call attention to what others can get for what they } \\
\text { accomplish }\end{array}$ & .22 & -.01 \\
\hline
\end{tabular}




\begin{tabular}{|c|c|c|c|c|}
\hline Nr. & $\begin{array}{l}\text { Leadership } \\
\text { factors }\end{array}$ & Leadership behaviours & $\begin{array}{c}\text { POE } \\
\text { followers }\end{array}$ & $\begin{array}{c}\text { Team } \\
\text { Performance } \\
\text { followers }\end{array}$ \\
\hline 6. & \multirow{3}{*}{$\begin{array}{l}\text { F6: } \\
\text { Management } \\
\text { by exception }\end{array}$} & I am satisfied when others meet the agreed-upon standards & .07 & .06 \\
\hline 13. & & As long as things are working, I do not try to change anything. & .05 & -.25 \\
\hline 20. & & $\begin{array}{l}\text { I tell others the standards they have to know to carry out } \\
\text { their work. }\end{array}$ & -.04 & .21 \\
\hline 7. & \multirow{3}{*}{$\begin{array}{l}\text { F7: Laissez- } \\
\text { faire } \\
\text { leadership }\end{array}$} & $\begin{array}{l}\text { I am content to let others continue working in the same way } \\
\text { always. }\end{array}$ & -.09 & .07 \\
\hline 14. & & Whatever others want to do is OK to me & -1.2 & -.12 \\
\hline 21. & & I ask no more of others than what is essential. & $.21 *$ & .15 \\
\hline
\end{tabular}

Only one leadership factor has all positive POE correlations, it is "Contingent reward". The contingent reward system is motivation-based approach that is used to reward employees that meet their identified goals and provides positive reinforcement for a job well done (Whetten, Cameron, 2002).

\section{Conclusions}

The theoretical literature analysis and the empirical research performed in this study have allowed to draw the following conclusions.

"Model of Human Energy" in an organization is important for: (1) the ability to maintain personal human energy and to use it correctly for leadership at the workplace, (2) the capacity to increase relational energy as an essential tool for managing the pedagogical process, (3) the possibility to growth productive team energy and (4) the opportunity to rise productive organizational energy.

The study has demonstrated how important it is to manage relational human energy relationship between subordinates, organization colleagues and team members to the mutual benefit of both parties. Special attention should be paid to the aspect of communication between leaders and followers of adult education.

Transformational leadership is important for productive team energy growth, because the leader's behaviour and traits implement the transforming human energy in empowering the followers. The skills required for a transformational leader need to be identified and trained to perform them, incentives must be clarified and implemented to keep followers motivated and inspired.

The results of the empirical study demonstrate that the correlation between team performance and productive organization energy of followers is significant and strong. It means that higher organizational energy is significantly and positively related to team performance and expected higher performance if higher energy is present. According to the correlation results, the leadership factor as "Contingent reward" has a positive impact on productive organizational energy and team performance.

The results of the research can be used to assist and help organizations in identifying practices, processes and initiatives which can have a positive impact on organizational energy and team performance.

\section{Bibliography}

1. Baker W.E. (2019). Emotional Energy, Relational Energy, and Organizational Energy: Toward a Multilevel Model. Annual Review of Organizational Psychology and Organizational Behavior, 6, 373-395. doi: 10.1146/annurev-orgpsych-012218-015047

2. Bass B.M. (1998). Transformational leadership: Industrial, military, and educational impact. Mahwah, NJ: Lawrence Erlbaum Associates.

3. Carmeli A., Spreitzer G.M. (2009). Trust, Connectivity, and Thriving: Implications for Innovative Behaviors at Work. Journal of Creative Behavior, 43(3), 169-191. doi: 10.1002/j.21626057.2009.tb01313.x

4. Cole M.S., Bruch H., Vogel B. (2008). Productive energy in the workplace: a measurement validation and linkage to collective outcomes. New York: Fort Worth, TX.

5. Freudenberger H.J. (1975). The staff burn-out syndrome in alternative institutions. Psychotherapy; Theory, Research and Practise, 12(1), 73-82. doi: 10.1037/h0086411 
6. Hargreaves A., Fink D. (2006). Redistributed Leadership for Sustainable Professional Learning Communities. Journal of School Leadership, 16(5), 550-565. doi: 10.1177/105268460601600507

7. Heaphy E.D., Dutton J.E. (2008). Positive Social Interactions and the Human Body at Work: Linking Organizations and Physiology. The Academy of Management Review, 33(1), 137-142. doi: 10.5465/amr.2008.27749365

8. Helou M.E., Nabhani M. (2016). Teachers' views on causes leading to their burnout. School leadership and Management, 36(5), 551-567. doi: 10.1080/13632434.2016.1247051

9. Hobfoll S.E., Shirom A. (2000). Conservation of Resources Theory: Applications to Stress and Management in the Workplace. In R.T. Golembiewski (Ed.), Handbook of Organization Behavior. New York: Marcel Dekker, 57-80.

10. Jacobson D.A. (2016). Causes and Effects of Teacher Burnout. (Doctoral Thesis, Walden University, Minneapolis, MN). Retrieved from https://scholarworks.waldenu.edu/cgi/viewcontent.cgi?article=3938\&context=dissertations

11. Kenny V.S. (2019). Employee productivity and organizational performance: A theoretical perspective. Retrieved from https://mpra.ub.uni-muenchen.de/93294/1/MPRA_paper_93294.pdf

12. Khumalo S.S. (2012). The role of transformational leadership in meeting school challenges: The role of transformational school leadership. LAP LAMBERT Academic Publishing.

13. Kříž E. (2013). The influence of teacher of practical teaching upon development of positive attitude towards work. In V. Dislere (Ed.), The Proceedings of the International Scientific Conference Rural Environment. Education. Personality (REEP), 6. Jelgava: LLU, 126-129. Retrieved from https://llufb.llu.lv/conference/REEP/2013/Latvia-Univ-Agricult_REEP_2013_ISSN_2255-808X-126-129.pdf

14. Leithwood K., Tomlinson D., Genge M. (1996). Transformational School Leadership. In K. Leithwood, J. Chapman, D. Corson, P. Hallinger, A. Hart (Eds,), International Handbook of Educational Leadership and Administration. Kluwer International Handbooks of Education, 1. Dordrecht: Springer, 785-840. doi: 10.1007/978-94-009-1573-2_23

15. Leme A., Maia I. (2015). Evaluation of fatigue at work in teachers using modern resources in the classroom. ScienceDirect, Procedia Manufacturing, 3, 4852-4859. doi: 10.1016/j.promfg.2015.07.601

16. Lexico. Oxford English and Spanish Dictionary, Thesaurus, and Spanish and English Translator. (2021). Retrieved from https://www.lexico.com/definition/energy

17. Luthans F., Avolio B.J. (2009). The "point" of positive organizational behavior. Journal of Organizational Behavior, 30(2), 291-307. doi: 10.1002/job.589

18. Quinn R.W., Dutton J.E. (2005). Coordination as Energy-in-Conversation. Academy of Management Review, 30(1), 38-40. doi: 10.5465/amr.2005.15281422

19. Rich B.L., Lepine J.A., Crawford E.R. (2010). Job engegament: Antecedents and effects in job perdomance. Academy of Management Journal, 53(3), 617-635. doi: 10.5465/amj.2010.51468988

20. Rowold J. (2005). Multifactor Leadership Questionnaire. New York: Mind Garden, Inc. Retrieved from http://www.mindgarden.com/documents/MLQGermanPsychometric.pdf

21. Ryan R.M., Frederick C.M. (1997). On energy, personality and health: Subjective vitality as a dynamic reflection of well-being. Journal of Personality, 65(3), 529-565. doi: 10.1111/j.14676494.1997.tb00326.x

22. Schwartz T., Gomez J., McCarthy C. (2010). The Way We're Working Isn't Working: The Four Forgotten Needs that Energize Great Performance. New York: Free Press.

23. Sun W., Xu A., Shang Y. (2014). Transformational leadership, team climate, and team performance within the NPD team: Evidence from China. Asia Pacific Journal of Management, 31, 127-147. doi: 10.1007/s10490-012-9327-3

24. Swaen B. (2015). Conceptual framework: Mediating variables. Retrieved from https://www.scribbr.com/dissertation/mediator-variables/

25. Teacher Effectiveness in Adult Education. (2020). Retrieved from http://lincs.ed.gov/programs/teachereffectiveness

26. Whetten D.A., Cameron K.S. (2002). Developing management skills ( $5^{\text {th }}$ ed.) Upper Saddle River, NY: Prentice-Hall.

27. Witt C. (2003). Ways of being: Potentiality and actuality in Aristotle's metaphysics. Ithaca, NY York: Cornel University Press. 